\author{
Adam Szot \\ Maria Curie-Sklodowska University \\ szot.adam@wp.pl
}

\title{
The Administrative Type of Application of Law
}

\author{
Administracyjny typ stosowania prawa
}

\begin{abstract}
The article is devoted to the specificity of application of law in the administrative type of this process. The subject is presented in the context of legal and extra-legal conditions of functioning of public administration that are linked to the necessity to implement public functions by administrative bodies. The article discusses the characteristic features of the administrative type of application of law, particularly when compared with judicial decision making. Special attention is also paid to decision making in the situation of existence of administrative approval as well as influence of politics and policies on decision making process.
\end{abstract}

Keywords: public administration, model of decision making, discretionary power, administrative approval, policies

\section{PUBLIC ADMINISTRATION AND THE ADMINISTRATIVE TYPE OF STATUTE LAW APPLICATION}

Understanding the application of law as a decision making process leading to issuance of a binding single decision by the authorised (competent) entity leads to the formulation of the thesis claiming the diversity of the processes. The diversity pertains to, on the one hand, the subject aspect of the processes: an individually assigned addressee (with all their characteristic features) and the multiplicity of decision making entities and, on the other hand the object aspect, i.e. the nature of the case (the area of activity) that is the focus of interest in the given process.

Taking into consideration the diversity of the entities that apply law, their position in the legal system vis a vis other authorities and the society, their objectives and the relevant fields of activity, we can discern different types of application of law. In the previous article, a division was proposed into the judicial and admin- 
istrative type of the process as the two basic (core) types, and two special types (derived types) i.e. mediation and management types.

A description of administrative decision making processes must begin by indicating the specific features of this type of application of law and. at the same time, the features that significantly influence the reasoning of the decision maker and - indirectly or more directly - the contents of the final decision.

However, beforehand it is necessary to adopt certain terminology relating to the comprehension of the phenomenon of "public administration". The meaning of the notion of "public administration" varies depending on the complex compound of social and political factors In jurisprudence (similarly to other fields of study that investigate the phenomenon), a broadly accepted definition of public administration has so far not been coined. It is actually underlined that, due to the dynamic nature of the environment of public administration and its constantly changing tasks, such a universal definition is impossible.

The attempts at grasping the essence of public administration that have been made so far can be qualified as one of the two approaches: the subject-approach (focusing on the bodies [subjects] that perform certain organisational and managerial tasks on behalf of the state and their structure) or the objective approach (focusing on the type of activity i.e. tasks and functions defined for the administrative body by the lawmaker).

In the contemporary Polish administrative law theory, the synthetic approach seems to dominate, combining the two approaches indicated above into an object approach. Within this understanding public administration is perceived as "the totality of organisational and executive activities that are aimed at achieving the common good by subjects (not necessarily state subjects), whereby the subjects are bound by statute in terms of the basis and form of their activity, and remain under social control". ${ }^{1}$

Public administration is responsible for implementation of the tasks defined by the lawmaker. The totality of the tasks encompasses, on the one hand, the activities associated with "straightforward" execution of the duties defined for the subject by the lawmaker, and on the other hand, creative activities related to the necessity of active and effective management of a defined part of reality. It is also emphasised that the leading principle of all activity of public administration bodies in democracies is their activity aimed at achieving the common good - in itself not finitely defined and axiologically changeable.

The group of public administration bodies includes, according to the contemporary approach, both public bodies and non-public bodies that perform public administration tasks as a result of lawmaker's prescription. Therefore, public ad-

${ }^{1}$ Z. Niewiadomski, Pojęcie administracji publicznej, [in:] System prawa administracyjnego, Vol. I: Instytucje prawa administracyjnego, eds. R. Hauser, Z. Niewiadomski, A. Wróbel, Warsaw 2010, s. 58. 
ministration includes every subject that has been entrusted with the performance of the tasks, regardless of the nature of the subject. A precise indication of the group of subjects is possible after analysing the specific legal regulations binding at the specific moment in time.

Approaching public administration from the object-subject perspective (taking into account the positioning of the decision making body within the structure of public authorities and the aim of the body's activity) facilitates a more complete depiction of the features of law application in the administrative type of these processes.

\section{SPECIFITY OF THE ADMINISTRATIVE TYPE OF THE APPLICATION OF LAW}

Referring to the heritage of Polish jurisprudence concerning the types of the application of $\mathrm{law}^{2}$, we can indicate several patterns that differentiate administrative- and judicial-processes of the application of law.

First of all, the administrative type of application of law is legal activity undertaken by the entity that has been entrusted with the performance of public administration tasks by the lawmaker. In the judicial type of application of law, on the contrary, the decision maker can be either a body of public authority or a non-public entity endowed with certain competences which enable it to perform the tasks.

Secondly, a characteristic trait of the decision maker in the administrative type is his or her organizational subordination. The decision maker constitutes a part of a complex administrative apparatus: the executive and management apparatus in the state. It is based either on hierarchical relationships of subordination and the resulting possibility for a body that is higher in this hierarchy to directly interfere in the activity of a body that is lower in the hierarchy, or functioning in a system of surveillance and control not directly linked to the hierarchical subordination, but with similar consequences. It must be pointed out, however, that the possibility to interfere in the activity of a particular administrative entity concerns its entire activity or its activity in chosen sectors, and not the content of individual decisions concerning a citizen (the addressee of the decision). The latter cannot take place in a state founded on the rule of law. However, it does not mean that such relationships cannot indirectly affect the content of the decisions in the application

${ }^{2}$ Cf. W. Dawidowicz, O stosowaniu prawa przez organy administracji państwowej, ,Zeszyty Naukowe Wydziału Prawa i Administracji Uniwersytetu Gdańskiego - Prawo” 1981, Vol. 9, pp. 6779; J. Wróblewski, Sąowe i pozasądowe stosowanie prawa - problemy teorii i praktyki, „Studia Prawno-Ekonomiczne" 1981, R. XXVI, pp. 7-21; W. Lang, J. Wróblewski, S. Zawadzki, Teoria państwa i prawa, Warsaw 1979, pp. 394-443; L. Leszczyński, Zagadnienia teorii stosowania prawa. Doktryna i tezy orzecznictwa, Zakamycze 2001, pp. 15-31. 
of law - it is, on the contrary, an indispensable characteristic of the administrative type of application of law, which does not and may not appear in the judicial type.

Thirdly, the process of application of law and the decision maker him- or herself are affected by political factors. In the most extreme cases, the law-applying entity or the person fulfilling this function is politically dependent. It stems from the fact that some public administration bodies are governed by politically nominated persons, who are politically responsible for their actions. ${ }^{3}$ The influence of politics on the administrative-type application of law, regardless of the understanding of politics and the symptoms of its influence, is inevitable and at the same time justified, whereas when it comes to application of law by state courts, such influence is unacceptable.

Fourthly, as in the judicial type, the addressee of the decision is not in any business or organizational relationship with the administrative body. The decision maker can at their discretion shape the rights and obligations of the decision's addressee, but the source of their authority are binding legal norms that grant the decision maker such a competence. This characteristic is an inherent element of the managerial type of decision making, which will be elaborated upon later in this article.

Fifthly, a public administration body is directly ("personally") interested in the content of its own decision. It is related to the necessity of performing tasks that the body is charged with. To put it simply, it is (or, at least, should be) in the interest of the body that every decision that it makes should allow it to fulfil these tasks or bring them closer to performance. The effectiveness of public administration body's actions is subject to verification in a complex organizational and political system. Consequently, the entity that applies law is accountable for the content of its decision to another body that, due to its position in the system or the authority granted to it, fulfils a supervisory and control function over rational management of the resources that the decision maker was endowed with, and over effective performance of the tasks that the decision maker was charged with. Beside legality of activities, the dominating criteria for evaluating a body's decision are praxeological criteria. Moreover, due to the fact that certain bodies are politically involved, their decisions and the consequences that follow are assessed from the point of view of correspondence with political objectives. In extreme cases, a person fulfilling the function of an administrative body may be dismissed from his position or face other consequences if the evaluation of his actions (as a whole, rarely in reference to individual decisions) is negative, regardless of the evaluation criterion used.

Sixthly, the foundations of all activity of a body that applies the law are competence norms decoded from certain norm-creating facts acknowledged and ac-

\footnotetext{
${ }^{3}$ More on the influence of politics on the administrative-type application of law can be found in later parts of the present excerpt.
} 
cepted as sources of law in a given legal system. In the culture of statutory law, they are usually universally binding legal regulations included in legal acts of appropriate legal validity. In principle, if such a situation is not permitted by the lawmaker, a body cannot delegate a competence it was entrusted with.

Seventhly, the scope of procedural activities executed by an administrative body in the process of application of law and the content of the final decision are defined by legal norms in force. Norms tend to grant a decision maker with certain decision making discretion. The appearance of such a decision-making margin is indispensable due to the permanent necessity to adapt decisions to the addressee's and the situation's individual characteristics in the changing socio-economic conditions. The lawmaker grants a certain scope of discretionary power to the administrative bodies, which allows them to set tasks without unequivocally defining the method of implementing them, to introduce general reference clauses to a legal text, to renounce from formulating legal definitions, or to formulate an authorization to make decisions in the scope of administrative approval. The source of discretionary power are also other factors which do not depend on the lawmaker's will and are linked to, among others, the imperfection of the lawmaker's language, specifics of the processes of the application of law, or the dynamism of social changes.

Eighthly, the decision maker's reasoning in the scope of its discretionary power (regardless of its source) is directed by a set of factors, in which law (i.e. legal rules and principles) plays the principal role and, at the same time, limits the factors impassably. At the same time, the process of application of law and the content of a particular decision can also be indirectly or directly influenced by organizational and political factors that can complement (and thus intensify their mutual influence), limit or even exclude one another. The influence of the two latter groups of factors is unacceptable in the judicial type of application of law.

Ninthly, the aim of the decisions on the application of law issued by public administration bodies is to define the rights and obligations of the decisions' addressees. For a law-applying body, issuing an individual decision is not only an end in itself, but at the same time an element of a wider process of managing a certain area of reality. Consequently, the body expects that each individual decision fulfils all the set criteria (legality, above all, but according to its preference also other criteria, such as economic effectiveness, correspondence with political aims etc.) and thus fits into the policy of application of law in the area the body manages.

Tenthly, decisions in the administrative type of application of law are issued in a situation where a conflict of interests may arise. ${ }^{4}$ During the whole decision

${ }^{4}$ Cf. M. Myślińska, A. Szot, Analiza konfliktowa w administracyjnym typie stosowania prawa (zarys problematyki), [in:] Państwo, prawo, polityka - księga poświęcona pamięci Profesora Hen- 
making process, different interests appear and affect one another, influencing the reasoning of the decision maker, and, as a consequence, the final content of the decision. Such a conflict is only potential and does not appear in every case.

The characteristics described above depict the similarities and differences in both judicial and administrative types of application of law. They are also binding in relation to the decisions that were issued by public administration bodies in the first instance and pertaining to external bodies. It is worth noting, however, that public administration bodies also issue a number of internal decisions regarding organizational and business matters concerning their current and strategic functioning. The difference between external and internal decision making is, above all, the relationship between the decision maker and the addressee of the decision. ${ }^{5}$ In this sense, decisions regarding an entity that is organizationally or officially subordinate to an administrative body belong to the managerial type, which is linked to the management of the administrative structure subordinate to the body. The managerial type of decision making is also characterized by other features that differentiate it from the administrative and judicial types of decision making. The features include: a catalogue of validation or derivative arguments, content and nature of the decision and control over the decision.

In simple terms, we can state that public administration bodies issue administrative decisions concerning external management, and managerial decisions regarding internal management.

\section{THE COURSE OF THE LAW APPLICATION PROCESS IN THE ADMINISTRATIVE TYPE}

The descriptive model of the process of the administrative type of application of law does not differ substantially from the judicial model of application of law presented in the previous part of this volume. As far as decision making is concerned, it comprises a series of reasonings of the law-applying entity. Every reasoning ends with a fragmentary decision being issued in order to pass a final decision with specific content.

The model of the process consists of two main stages: the preparatory stage, during which the decision maker establishes the factual circumstances and the legal status of a case, and the principal stage, which leads directly to the formula-

ryka Groszyka, Lublin 2012, pp. 230-241; P.J. Suwaj, Konflikt interesów w administracji publicznej, Warsaw 2009, passim; H. Groszyk, A. Korybski, Konflikt interesów i prawo, Warsaw 1990, passim.

${ }^{5}$ Cf. i.a. W. Lang, J. Wróblewski, S. Zawadzki, op. cit., p. 412; A. Błaś, Z problematyki realizacji norm prawa administracyjnego, „Studia Iuridica” 1996, Vol. XXXII, pp. 58-59; L. Leszczyński, Podstawa decyzji stosowania prawa administracyjnego. Ustalenia walidacyjne, [in:] System prawa administracyjnego, Vol. IV: Wyktadnia w prawie administracyjnym, eds. R. Hauser, Z. Niewiadomski, A. Wróbel, Warsaw 2012, pp. 93-94. 
tion of the final decision and includes the qualification of facts from the point of view of the reconstructed normative basis of the decision, as well as establishing the consequences of the qualification.

In the case of the administrative type of application of law, the aforementioned model should be complemented with one more stage that precedes chronologically all the indicated reasonings: the pre-decision stage, during which the decision to start the process of application of law is made; therefore, this stage determines the existence of the process. The judicial type of decision making is based, above all (depending on the detailed preference of the lawmaker) on the principle of the accusatorial procedure. The court is obliged to "wait" for the appropriate application to be filed. Public administration bodies, on the other hand, may take action both upon request and ex officio.

The appearance of the pre-decision stage can be fully seen during processes initiated by the body itself due to a necessity to perform a task set for the body. The lawmaker often gives public administration bodies certain tasks (formulated in a more or less detailed way), but does not indicate the methods of their performance. In such a case, the decision maker is obliged to choose the mode of action (the method of task performance) that, according to the lawmaker, would allow the body to achieve a defined objective in the fullest and most effective way, or at least facilitate achieving it. Such a mode of action is, for example, issuing an individual decision concerning application of law. Should the body develop a conviction during the pre-decision stage that it is the right path (regardless of the criteria of choice it is guided by), it will make a decision to start the process of application of law that will lead to issuing such a decision. At the same time, a decision made at this stage of the process will become its first individual decision.

The decision to start applying the law during the pre-decision stage has to be preceded by a search for the competence norm that enables the body to issue the decision concerning the citizen (the future addressee). It is worth emphasizing that in the rule-of-law state, all imperative activity of the public administration is acceptable only if appropriate bases for it exist in the law. In other words, the mere fact of the existence of a task is not and cannot constitute a basis for interference in a citizen's rights and obligations. In order to do so, an express authorization in the competence norm needs to be formulated. ${ }^{6}$

The pre-decision stage appears in all kinds of cases that are an object of interest of public administration bodies. However, depending on whether or not the lawmaker grants the law-applying entity a certain margin of administrative discretion to make a decision on the issue of starting a law application process, the

${ }^{6}$ Cf. M. Matczak, Kompetencja organu administracji publicznej, Warsaw 2004, p. 192. "Task norms do not have the nature of a specified norm of material law; they are systemic and as such do not constitute a basis to formulate individual rights and requests". Cf. judgement of the Kielce Voivodeship Administrative Court of 24 October 2013 I SA/Ke 424/13, CBOSA. 
course of the decision and its final effect will be different as far as the possibility or an obligation to make a decision on starting a legal proceeding is concerned. If the legal norms in force oblige the body to engage in every case on external request (regardless whether or not the request was filed by the future addressee of the decision), the body will have no freedom to decide whether to engage in the case or not, and the pre-decision stage will be reduced to minimum in terms of time and complexity of the decision maker's reasonings.

The facts established in the pre-decision stage, depending on the detailed procedural solutions, may become (automatically, in a sense) part of the reasonings of the preparatory stage without the need to re-conduct the reasonings. It might as well be necessary to verify the correctness of the reasonings or to conduct the reasonings another time (for example due to the fact that the future addressee of the decision was not able to participate in the performance of a given action).

The decision to start the process of the application of law is linked to the transition to the two subsequent stages: the preparatory and decision stages that are executed similarly as in the judicial type. However, there may appear differences (in the material aspect) between reasonings undertaken on these stages in both types of the application of law, independently from the differences resulting from legal norms that regulate the course of court or administrative procedure (the procedural aspect).

\section{DIFFERENCES IN ADMINISTRATIVE-TYPE REASONING}

Compared to judicial type, the reasonings in the process of the application of law by public administration bodies may be somewhat different. The differences are a consequence of the characteristics of administrative decision making and the preferences of the lawmaker considering the regulation of certain areas of social life. At the same time, these characteristics are not of universal nature and may change depending on the type of legal culture, political regime, axiology of the legal system, or axiology of the selected area or sub-area of law, as well as the instance at which the decision is made.

The process of establishing the facts in a case consists in cognitive reasoning with certain elements of legal reasoning, similarly to judicial type. ${ }^{7}$ Differences in the process of establishing the facts in both types, except for those which are a consequence of detailed procedural solutions (judicial and administrative), are linked, above all, to the fact that not only the past events, but also the current (present) state of reality are of greater importance to a public administration body than to a court.

\footnotetext{
${ }^{7}$ L. Leszczyński. Zagadnienia teorii stosowania prawa ..., pp. 65-71.
} 
Additionally, due to the necessity to perform tasks, a public administration body is interested in the effects of its decision, in particular whether it will bring it closer to the performance of a task. At the same time, in order for the body to assess it on the stage of designing the content of the decision or the subsequent evaluation of its effects, the body has to answer the question how the reality in which a task it was charged with has been performed should look like. Such a specific situation leads to the appearance of another group of "facts" that constitute the object of the decision maker's interest in the administrative-type application of law: "the future imagined facts", which are, in fact, an anticipation of the performed task. Establishing them may significantly affect the reasonings of the administrative body, including those related to the decision to start the process of the application of law in the pre-decision stage, or to the shape of the final decision of the process, based on the construction of administrative approval.

In relation to reasonings linked to the search for the source of the normative basis for the decision in the continental legal culture, it is worth emphasizing that legal provisions dominate as validation arguments. At the same time, the practice of referring to other decisions concerning the application of law or open criteria as norm-creating facts is limited.

Reference to open criteria is - in principle - possible only if there exists an express authorisation for doing so in the form of a general reference clause. A lack of such an authorisation, in fact, deprives the administrative body of the possibility to include extralegal factors in the decision making process, especially as decisionjustifying arguments. At the same time, the doctrine emphasizes the influence of praxiological criteria on the process of the application of law, whether the applied law system permits for the authorisation or not. This is linked to the requirement for the body to effectively manage the area of social life it was charged with. This influence is factual, not legal. Therefore, such arguments cannot constitute the basis for issuing an imperative decision concerning an external entity.

Regardless of the type of application of law, a lack of legal possibility of acknowledging open criteria as validation arguments does not mean that they have no influence on the body's reasonings in the process of application of law. Thus, such open criteria can complement the results of an interpretation obtained from strictly juridical arguments, reinforcing the decision maker's conviction that the results of his reasoning are correct. They can also affect the content of the final decision if the lawmaker grants the entity that applies the law with a certain amount of discretionary power in this scope.

Other decisions concerning the application of law may become validation arguments - if such a possibility is permitted by the lawmaker. However, they usually complement or verify the results of interpretation of legal provisions. An analysis of the Polish practice in administrative decision making shows that decision makers refer to other decisions concerning the application of law much less 
often than in the judicial type. If it does take place, it concerns earlier judicial decisions rather than other administrative ones.

Of course, it does not prevent those other (judicial and administrative) decisions concerning the application of law from influencing the course of the decision making process and the content of the final decision. It does have a pragmatic justification - a body responsible for its actions wants to prevent consistent challenging of its decisions or a negative assessment of its functioning. It may therefore be willing to issue decisions that "fit into", broadly speaking, the decision making policy of the controlling body or the jurisprudence.

Differences in comparison to the judicial decision making type are also noticeable when we look at using legal provisions as validation arguments. This results mainly from the fact that administrative bodies are limited by these provisions regardless of their rank. It is almost impossible (in the Polish legal order) to use the lex superior derogat legi inferiori principle, even if there is an obvious discrepancy between the provisions of lower legal validity (the norm decoded from them) and the provisions situated higher in the hierarchy of sources of law (and it is impossible to find a normative compromise between them), without any possibility of finding a normative compromise between them. It is of special significance if one of such provisions has its source in the Constitution or the EU law.

On the other hand, using the lex superior principle is acceptable and necessary in the case of a collision between provisions of universally and internally binding law. However, the Polish administrative law theory emphasizes the phenomenon of the "reversed hierarchy of the sources of law" (as undesirable as it is), which manifests itself in the tendency of administrative bodies to "prefer" the provisions coming from inside the administration to the universally binding ones.

As for derivative reasonings, it is noteworthy that they are to a larger extent determined by the diversity of the conditions in which administrative bodies function than in the judicial type. This means that the process of normative reconstruction of the decision's basis is influenced by juridical, political and praxeological factors.

However, linguistic interpretation plays the key role in these processes. It is desirable because of the fact that administration enters imperatively into the area of rights and obligations of its decision's addressees. For this reason, opinions of the doctrine and legal practice emphasize that in order to prevent the bodies that do not have the appropriate knowledge from dealing with negative consequences, administrative bodies should aim at obtaining an interpretation that would not surprise the parties to a case (for example, by prohibiting interpretation of exceptions to the prejudice of the addressee). It is also linked to the execution of one of the chief principles of a democratic rule of law: the principle of deepening the reliance on the state and its bodies.

\footnotetext{
${ }^{8}$ Cf. J. Zimmermann, Prawo administracyjne, Cracow 2005, p. 362.
} 
It is, however, necessary to emphasize that the dominance of linguistic interpretation is not absolute and needs relativisation in individual areas of legal-administrative regulation. This means that in some of the sub-areas of administrative law, a departure from the results of such an interpretation is undesirable, while in others, due to their axiological or praxeological involvement, it is justified and necessary to correct the results by using systemic or purpose-functional rules. Further relativisation in this scope is linked to the type of the norm which is the object of the decision maker's interest on the given stage.

At the same time, however, any departure from the wording of the provision has to be justified in a double sense, i.e. there must exist rational reasons for it, and the motives of such a decision have to be justified.

Another important difference between the judicial and the administrative type is the scope of discretion of the administrative bodies on the stage of formulating some of the final decisions. It involves the lawmaker using the construct of administrative approval which provides the possibility of choosing between at least two almost equivalent decisions in order to issue one that is, in the body's view, the most appropriate, based on certain criteria of the choice of consequences.

\section{DECISION MAKING IN ADMINISTRATIVE APPROVAL}

Research on various aspects of administrative approval has been a prominent topic in both Polish and foreign doctrine and theory of law. Discretionary power of public administration in processes of the application of law is often analysed from the point of view of administrative approval.

Administrative approval is a construct that has noticeably evolved over the centuries. ${ }^{9}$ The notion that preceded administrative approval was "discretion", which was treated as an area of administrative action which was not limited by legal provisions. It was believed that what was not regulated by provisions belonged to the area of discretion in which administration could act without the need to refer to any legal foundation. ${ }^{10}$ Over time, the scope of this power became more and more limited due to, among others, attempts at creating inner borders of discretion or the emergence of the concept of the rule of law. Nowadays, discretion concerns the content of a decision and has lost the part of the construct that dealt with the question whether to issue a decision or not. ${ }^{11}$

\footnotetext{
${ }^{9}$ More on the evolution of these views in the Polish jurisprudence: cf. i.a. M. Mincer, Uznanie administracyjne, Toruń 1983, passim; M. Jaśkowska, Uznanie administracyjne a inne formy władzy dyskrecjonalnej administracji publicznej, [in:] System prawa administracyjnego, Vol. I: Instytucje prawa..., pp. 213-303; Z. Duniewska, Istota i granice dyskrecjonalnej wtadzy administracji w świetle standardów europejskich, „Studia Prawno-Ekonomiczne” 1999, R. LIX, pp. 9-18.

${ }^{10} \mathrm{~J}$. Zimmermann, op. cit., p. 365.

${ }^{11}$ L. Leszczyński, Zagadnienia teorii stosowania prawa..., p. 45.
} 
Today, the Polish doctrine and judicial practice equate this notion ${ }^{12}$ with the final stage of the process of application of law - the stage of establishing legal consequences. Therefore, administrative approval is not to be confused with other displays of discretionary power of a law-applying entity, including those linked to free assessment of evidence or interpretation of fuzzy concepts.

Administrative approval expressed in such a way consists in granting the administrative body with the possibility of choosing between two or more legally authorized and equivalent solutions. Such a situation takes place when the legal norm does not unequivocally define the legal effect of factual circumstances, but expressly leaves the choice of such effect to the administration.

Such a choice is not, however, arbitrary; it has to be based on the facts of the case and take into account the directives of the choice of consequences. These directives can be divided into two main groups: the first-order choice of consequences directives and the second-order choice of consequences directives.

Directives in the first group are introduced by the lawmaker in the norm which is the foundation for issuing a decision based on administrative approval. The lawmaker can, however, renounce the possibility of indicating specific criteria that the decision maker should take into consideration when formulating the decision. These directives can also result from the content of legal provisions, which express the axiology of the legal system or task norms that indicate the goal that the body should strive to achieve.

The influence of the directives from the second group is linked to, on the other hand, non-legal (organizational and political) factors affecting the decision making entity and the content of the decisions it issues. Such factors are various recommendations and guidelines that the body receives from the surroundings but that do not come from the lawmaker.

A law-applying body is bound by the directives of the choice of first-order consequences, as they consider the legality of their actions. Its decisions, made in the scope of administrative approval, are subject to assessment from the point of view of the criteria included in those directives, which can also be completed by directives belonging to the second group. The latter will gain exceptional significance in the case of a lack of criteria of the choice of consequences that are unequivocally formulated by the lawmaker. It needs emphasizing, however, that they cannot limit or eliminate the possibility of using first-order directives, nor can they lead to results that contradict them.

The administrative body is not, however, legally limited by the directives of the choice of the second order. Nevertheless, this fact does not diminish their sig-

${ }^{12}$ On changes in perception of administrative approval, cf. i.a.: A. Ostrowska, Teoretycznoprawne aspekty uznania administracyjnego, [in:] Wykładnia prawa-odrębności w wybranych gatęziach prawa, ed. L. Leszczyński, Lublin 2006, p. 21. 
nificance. Directives of the second group can be factually binding, which results from the fact that the body functions in a complex organizational-political system and takes responsibility for the content of the decision it issues.

Administrative approval is a display of discretion of the law-applying body that influences in the most visible and "tangible" way the content of a decision that defines the rights and obligations of a citizen. The possibility of a whole set of factors influencing the decision maker, out of which law is the main one but not the only one, justifies the need for the existence of an effective system that could be used to verify the content of administrative bodies' decisions made within the scope of discretionary power.

\section{THE INFLUENCE OF POLICIES ON THE ADMINISTRATIVE TYPE OF APPLICATION OF LAW}

In the discussions on the influence of politics on administrative decision making, the threats it can bring about are often mentioned, whereas the complexity, as well as the multiplicity of the threads and levels of this problem remain unnoticed.

The influence of politics on the decision maker and the decision making process itself is an inherent characteristic of the administrative type of application of law. This influence is effective on two levels: the first one results from the fact that public administration is the executive apparatus of the state (the external aspect), and the other one related to the functioning of administrative bodies in a complex system of subordination (the internal aspect). ${ }^{13}$

The first level is related to entrusting the administration with certain tasks which are a consequence of the assumed vision of the state, its aims and functions. In such a view, political decisions can influence the administration's actions in three ways. First, it can be done through lawmaking, which is especially typical of civil law culture. Political values, through measures that are acceptable in a given legal system, bring about changes in the content of the binding legal norms. The norms created in such a way indicate the aims that the administration must strive to fulfil. They also define the acceptable forms of the pursuit of such aims, and the impassable limits of public administration bodies' activity. Second, it is linked to the necessity for the administration to act for the "common good", which in itself is subject to axiological changes and depends on the values preferred by the sovereign in a given historical moment. Third, the influence of political values can be observed in relation to a given administrative policy (as one of a number of detailed policies implemented in the internal affairs of a state), in which the law-

${ }^{13}$ For these two levels see: J. Boć (Pojęcie administracji, [in:] Prawo administracyjne, ed. J. Boć, Wrocław 2010, p. 19.) who uses the terms "policy towards administration" ("polityka wobec administracji") and "politics in administration" ("polityka w administracji”). 
maker grants the administration with a certain degree of freedom (discretion) in the choice of directions or forms of activity. In such a case, the policy can directly or indirectly influence that choice. ${ }^{14}$

Having analysed the above questions, one can assume that the political environment is a system of non-legal and postulative statements as to where, when and how to use material and organizational capacities of the state and of the local government ${ }^{15}$, either taking no account of the political line of a given political party (and in this sense the term "politics" draws near to the term "policies"), or taking it into account.

Noticing the influence of the values preferred by the dominating political parties and the activities of the administration make it possible to recognize the relationships that can appear on the second of the aforementioned levels.

Some public administration bodies, or, to be precise, their leaders, are a combination of the political and the administrative functions. Whether they are appointed through political nomination or through elections (often voted for by a political party in the elections), they take responsibility for the quality of their actions and the content of their decisions (as a whole or, less frequently, for individual decisions) from the point of view of conformity with the values preferred by the entity that has nominated or appointed them. If this is the case, the bodies are directly interested in aligning their activity with the pre-established criteria.

Of course, in a state based on the rule of law, the influence of political factors cannot lead to decisions that do not match the content of the legal norms in force. ${ }^{16}$ Therefore, the influence of political factors on administration's activity is possible if it does not collide with the law in force and does not result in such a collision.

At the same time, the second of the aforementioned levels provides yet another understanding of the political environment and its influence on the processes of application of law. The policy of decision making can be understood as a certain way of performing tasks and, as a consequence, a way of acting in cases of a given type, or a way of managing resources that are available to the body.

The policy of decision making and its component, the policy of application of law can be shaped in cooperation with a certain public administration body that makes decisions afterwards, or independently from such a body, but still within the scope of the administration's organizational system. This means that the ad-

${ }^{14}$ In literature, it is emphasized that administrative policy is sometimes equated to public policy. Cf. M. Kulesza, D. Sześciło, Polityka administracyjna i zarządzanie publiczne, Warsaw 2013, pp. 18-19 and literature referred to there.

${ }^{15} \mathrm{~J}$. Boć, op. cit., p. 18.

${ }^{16}$ The doctrine emphasizes that public administration should be excluded from the area of politics, but it cannot be excluded from the area of policy. Cf. H. Izdebski, Fundamenty współczesnych państw, Warsaw 2007, pp. 212-213. Cf. M. Stefaniuk, Działanie administracji publicznej w ujęciu nauk administracyjnych, Lublin 2009, p. 113. 
ministration sets detailed tasks for itself (which, in fact, complement the ones set by the lawmaker), as well as ways and methods of their performance.

This, in turn, leads essentially to a more or less conscious activity. Consequently, decision making borderlines are created, which are a result of certain internal guidelines or practices concerning the ways of dealing with similar cases. In the Polish legal system, public administration bodies do not have the competence to determine binding decision making delineation for other bodies (to formulate specific "precedents"). Guidelines coming from the decision making policy, regardless of the way it is shaped, the level of formalities and the motives that the body is guided by when referring to them can influence the way in which the body uses the discretionary power it is entitled to, especially in relation to the decisions made within the scope of administrative approval.

\section{LITERATURE}

Błaś A., Z problematyki realizacji norm prawa administracyjnego, „Studia Iuridica” 1996, Vol. XXXII.

Boć J., Pojęcie administracji, [in:] Prawo administracyjne, ed. J. Boć, Wrocław 2010.

Dawidowicz W., O stosowaniu prawa przez organy administracji państwowej, „Zeszyty Naukowe Wydziału Prawa i Administracji Uniwersytetu Gdańskiego - Prawo” 1981, Vol. 9.

Duniewska Z., Istota i granice dyskrecjonalnej władzy administracyjnej w świetle standardów europejskich, „Studia Prawno-Ekonomiczne” 1999, R. LIX.

Groszyk H., Korybski A., Konflikt interesów i prawo, Warszawa 1990.

Izdebski H., Fundamenty współczesnych państw, Warsaw 2007.

Jaśkowska M., Uznanie administracyjne a inne formy władzy dyskrecjonalnej administracji publicznej, [in:] System prawa administracyjnego, Vol. I: Instytucje prawa administracyjnego, eds. R. Hauser, Z. Niewiadomski, A. Wróbel, Warsaw 2010.

Kulesza M., Sześciło D., Polityka administracyjna i zarządzanie publiczne, Warsaw 2013.

Lang W., Wróblewski J., Zawadzki S., Teoria państwa i prawa, Warsaw 1979.

Leszczyński L., Podstawa decyzji stosowania prawa administracyjnego. Ustalenia walidacyjne, [in:] System prawa administracyjnego, Vol. IV: Wykładnia w prawie administracyjnym, eds. R. Hauser, Z. Niewiadomski, A. Wróbel, Warsaw 2012.

Leszczyński L., Zagadnienia teorii stosowania prawa. Doktryna i tezy orzecznictwa, Zakamycze 2001.

Matczak M., Kompetencja organu administracji publicznej, Warsaw 2004.

Mincer M., Uznanie administracyjne, Torun 1983.

Myślińska M., Szot A., Analiza konfliktowa w administracyjnym typie stosowania prawa (zarys problematyki), [in:] Państwo, prawo, polityka - księga poświęcona pamięci Profesora Henryka Groszyka, Lublin 2012.

Niewiadomski Z., Pojęcie administracji publicznej, [in:] System prawa administracyjnego, Vol. I: Instytucje prawa administracyjnego, eds. R. Hauser, Z. Niewiadomski, A. Wróbel, Warsaw 2010.

Ostrowska A., Teoretycznoprawne aspekty uznania administracyjnego, [in:] Wyktadnia prawa - odrębności w wybranych gatęziach prawa, ed. L. Leszczyński, Lublin 2006.

Stefaniuk M., Działanie administracji publicznej w ujęciu nauk administracyjnych, Lublin 2009. 
Suwaj P.J., Konflikt interesów w administracji publicznej, Warsaw 2009.

Wróblewski J., Sadowe i pozasądowe stosowanie prawa - problemy teorii i praktyki, „Studia Prawno-Ekonomiczne" 1981, R. XXVI.

Zimmermann J., Prawo administracyjne, Cracow 2005.

\section{SUMMARY}

Legal and extra-legal conditions of functioning of public administration can significantly influence decisions making processes undertaken by public administration bodies and can lead to formation of certain, relatively stable, tendencies within the policy of application of law processes. At the same time administrative law application process differs from the judicial one. One of the differentiating features consists in supplementing the model of the process with an additional phase - the pre-decision phase. The differences are visible also in legal reasoning and arguments that justify the selection of legal basis of decisions or legal interpretation as well as decision based on administrative approval (which allows administrative body to choose between at least two legally permissible decisions).

\section{STRESZCZENIE}

Niniejszy artykuł został poświęcony omówieniu specyfiki stosowania prawa w typie administracyjnym. Poprzedza je ogólna refleksja na temat uwarunkowań prawnych i pozaprawnych funkcjonowania administracji publicznej, związanych z koniecznością dążenia przez jej organy do realizacji zadań państwa. Uwarunkowania te w znaczny sposób mogą wpływać na procesy podejmowania decyzji zarówno w ujęciu jednostkowym, jak i w odniesieniu do kształtowania się pewnych linii decyzyjnych. W dalszej części omówiono cechy charakterystyczne administracyjnego typu stosowania prawa, w szczególności w zestawieniu z orzeczniczą działalnością sądów. Odrębności te wiążą się przede wszystkim $\mathrm{z}$ faktem, iż stosowanie prawa $\mathrm{w}$ typie administracyjnym jest elementem szeroko rozumianego zarządzania w sferze publicznej. Różnice dostrzegalne są również w przebiegu rozumowań podejmowanych przed decydenta. Szczególną uwagę warto zwrócić na formułowanie treści decyzji finalnej w ramach uznania administracyjnego, które uprawnia organ do wyboru tego - spośród co najmniej dwóch prawnie dopuszczalnych rozstrzygnięć - które pełniej realizuje założoną politykę decydowania (stosowania prawa). To ostatnie zagadnienie zostało szerzej omówione w ramach ostatniej części artykułu, w której zanalizowano wpływ polityki na proces stosowania prawa i rozumowania organu podejmującego decyzję. 